ISSN 0258-7122 (Print), 2408-8293 (Online)

Bangladesh J. Agril. Res. 42(2): 387-392, June 2017

Short Communication

\title{
GROWTH RATES OF FRUITS CULTIVATION IN HILLY AREAS OF BANGLADESH
}

\author{
M. A. HOSSAIN ${ }^{1}$, M. KHATUN ${ }^{2}$, M. A. MATIN ${ }^{3}$ \\ AND M. F. DEWAN ${ }^{4}$
}

Keywords: Hill regions, fruits, area, production, productivity, trend and growth rate.

The fruits have vital role in making human diet balanced. Standard of living of people generally judged by per capita production and consumption of fruits (Bairwa et al., 2012). Bangladesh is producing a variety of fruits owing to its various agro-climatic conditions. Perennial crops like trees normally remain as grossly under exploited potential resources in hill agriculture. Fruits are usually grown by the hilly farmers and these crops give them few opportunities. Fruits play a unique role in developing countries like Bangladesh, both economic and social sphere for improving income and nutritional status, particularly for hilly people. Besides nutritional advantages, there are other competing reasons for which fruit production in hilly areas deserves preference. These include: (i) due to agro climatic features, horticulture is the only vocation through which higher income per unit of land can be generated. (ii) fruit farming helps in proper utilization of areas (iii) fruit cultivation allows optimum utilization of the gift of nature in making it possible to upgrade inferior fruit trees into superior ones by top working and by adopting other techniques of vegetative propagation (iv) given suitable combination, fruit farming can even be taken as a complementary occupation in hills to a set of other business propositions (Wasim, 2011).

Siddiqu (2001) reported that very good quality litchi grows in the Chittagong district in hill area. But the rate of expansion is extremely slow, which may be due to prevailing social unrest and difficulty in establishing new orchards. Reviewing all these paper, there is a clear thing that there was no such research about growth rates of major fruits in hill regions particularly in upazilla level. This type of study yet not been done in hill areas. The growth rate of area, production and yield of fruits and other analytical aspect in this report would help to facilitate, interpretation and forecasting on the future development of fruits in the hilly areas. Objective of the study is to estimate the trend and growth rates of area, production and productivity of fruits.

The secondary data on area, production, productivity were obtained from DAE (upazila level fruits data are not available in BBS publication) data of covering the period from 2006 to 2012 depending on the availability (data of previous year

\footnotetext{
${ }^{1 \& 3}$ Principal Scientific Officer, Agricultural Economics Division, Bangladesh Agricultural Research Institute (BARI), Gazipur, ${ }^{2}$ Scientific Officer, Agricultural Economics Division, BARI, Gazipur, ${ }^{4}$ Assistant Professor, Department of Economics and Poverty Study, Noakhali Science and Technology University, Noakhali, Bangladesh.
} 
is not found in the upazila level). The information regarding the area and production of selected fruits were collected from respective upazila with the purpose of understanding the present trend of area and production in the recent years (2006/07 to 2011/2012). Growth rate was estimated for selected upazila, namely Juri and Sreemongal upazila of Moulavibazar, Matiranga and Dighinala upazila of Khagrachari, Naniarchar and sadar upazila of Rangamati and Bandarban sadar of Bandarban district. To estimate the growth rate of area, production and productivity of different fruits in selected areas of Bangladesh for the period from 2006-07 to 2011-12, the following semi log exponential form was used (Gujarati, 1998):

$\mathrm{Y}=\mathrm{ae}^{\mathrm{bti}}$

Or In $\mathrm{Y}=$ Ina+bti

Or InY $=\mathrm{A}+$ bti (here $\mathrm{A}=\ln \mathrm{a})$

Where, $\mathrm{A}=$ Intercept

$\mathrm{Y}=$ Quantity of major fruits production, area and productivity

$\mathrm{b}=$ Growth rate in ratio scale and when multiplied by 100 , it express percentage growth

i.e, annual growth rate

$\mathrm{t}_{\mathrm{i}}=$ time, $\mathrm{i}=1,2,3$, 15 years

In = natural log of the variable

Trends of average area is shown in figure 1 which depicts that more lands was used to cultivate banana over the year 2006-07 to 2011-2012 followed by pineapple, jackfruit, mango, litchi, orange. But the trend of all fruits area was upward. Area under cultivation of banana and mango was increased more compared to pineapple, jackfruit, litchi and orange.

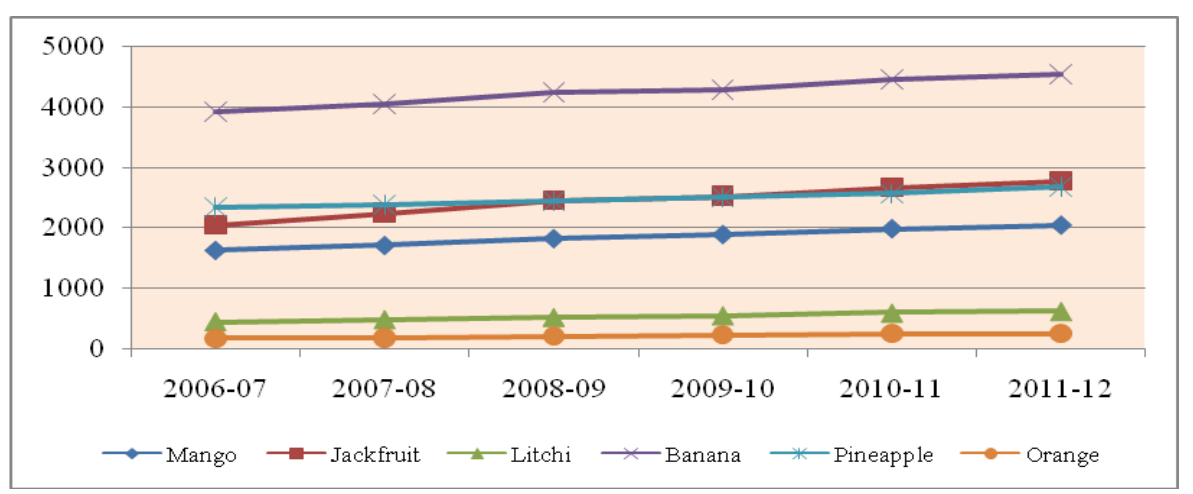

Fig. 1. Trend line of area (ha) of different fruits in all location.

Trends of average production is shown in figure 2 which depicts that production of banana in hill areas over the year 2006-07 to 2011-2012 was more than other fruits as more areas were under the cultivation of banana. It was observed that 
the trend of all fruits production was upward. Production of banana and jackfruit was highly increased compared to mango, pineapple, litchi and orange.

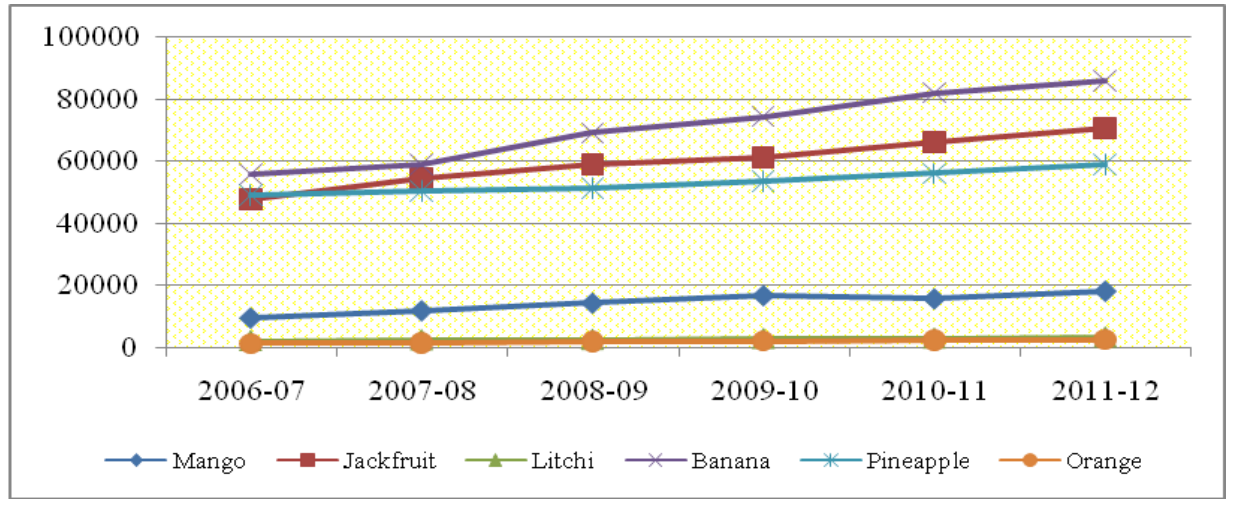

Fig. 2. Trend line of production (ton) of different fruits in all location.

Figure 3 depicts that productivity of fruits in hill region over the year 2006-07 to 2011-2012 was upward. Productivity of banana, mango, pineapple, jackfruit, litchi and orange was slightly increased over the year. The area, production and productivity of different fruits in all study upazilas were found to be increasing. Fruits cultivation is getting popular in hilly areas over the last several years. The farmers were growing local variety instead of high yielding variety with minimum investment. Lack of improved management, poor knowledge of farmers, lack of efficient marketing system, low demand etc. is substantially hindering the higher production.

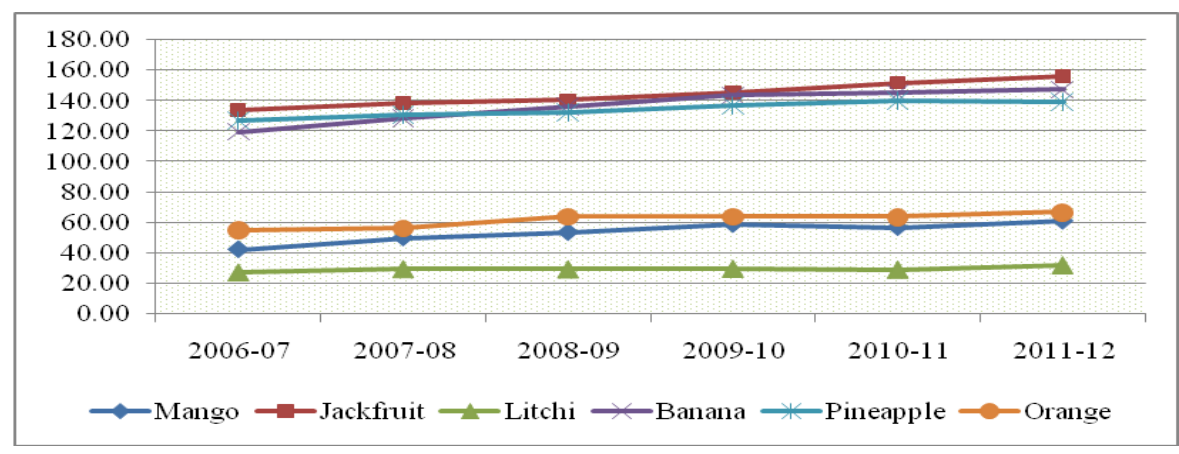

Fig 3. Trend line of productivity (ton/ha) of different fruits in all location.

The growth rates of area, production and productivity of different fruits in different locations are shown in Table 1. From the growth rates of area, production and productivity of mango, it is seen that growth rate of area was increased significantly in all upazilas. Dighinala upazila was found the highest growth rate $(11.91 \%)$ followed by Juri upazila (5.67\%) and the lowest growth rate of area was found for Naniarchar upazila which was about $1.17 \%$ per year. 
Table 1. Growth rate of area, production and productivity of fruits in selected areas of Bangladesh for the period of 2006/07-2011/12

\begin{tabular}{|c|c|c|c|c|c|c|c|c|}
\hline Fruits & Indicators & Juri & Sreemongal & Matiranga & Dighinala & Naniarchar & $\begin{array}{c}\text { Rangamati } \\
\text { Sadar }\end{array}$ & $\begin{array}{c}\text { Bandarban } \\
\text { Sadar }\end{array}$ \\
\hline \multirow{3}{*}{$\begin{array}{l}0 \\
\stackrel{\infty}{\Xi} \\
\stackrel{\Xi}{\Sigma}\end{array}$} & Area & $5.67 * *$ & $2.88 * * *$ & $3.69 * * *$ & $11.91 * *$ & $1.17 * *$ & $4.75 * *$ & $3.87 * *$ \\
\hline & Production & $12.96 * * *$ & $3.90 * * *$ & $8.94 * * *$ & $15.93 * *$ & $16.10 * *$ & $10.70 * *$ & $11.66 * *$ \\
\hline & Productivity & $7.29 * *$ & $1.02 * *$ & $5.25 * * *$ & $4.02 * *$ & $14.93 * *$ & $5.95 * *$ & 7.79 \\
\hline \multirow{3}{*}{ 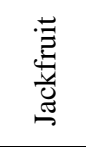 } & Area & $6.03 * *$ & - & $2.66 * * *$ & $10.84 * *$ & $7.84 *$ & $0.67 * *$ & $6.06 * *$ \\
\hline & Production & $16.30 * * *$ & - & $5.20 * * *$ & $17.99 * *$ & $14.85 * * *$ & -0.28 & $8.62 * *$ \\
\hline & Productivity & $10.27 * *$ & - & $2.54 * * *$ & $7.15^{* *}$ & $7.01 * * *$ & -0.96 & 2.57 \\
\hline \multirow{3}{*}{ : } & Area & $7.30 * *$ & - & $8.01 * * *$ & $5.89 * * *$ & $4.01 * * *$ & $4.69 * *$ & $8.40 * *$ \\
\hline & Production & $14.17 * * *$ & - & $12.54 * * *$ & $7.22 * * *$ & $7.96 * *$ & $5.01 * *$ & $14.84 * *$ \\
\hline & Productivity & $6.87 * *$ & - & 4.53 & $1.34 * * *$ & 3.85 & 0.33 & $6.43 *$ \\
\hline \multirow{3}{*}{ 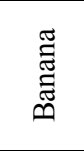 } & Area & $2.08 * *$ & $6.77 * * *$ & $3.60 * * *$ & $10.96 * * *$ & $1.69 * *$ & $5.10 * *$ & $1.28 * *$ \\
\hline & Production & $4.29 * * *$ & $4.29 * * *$ & $4.29 * * *$ & $4.29 * * *$ & $4.29 * * *$ & $4.29 * * *$ & $4.29 * * *$ \\
\hline & Productivity & $2.21 * *$ & $2.21 * *$ & $2.21 * *$ & $2.21 * *$ & $2.21 * *$ & $2.21 * *$ & $2.21 * *$ \\
\hline \multirow{3}{*}{$\frac{0}{\stackrel{0}{\vec{E}}}$} & Area & $11.27 * * *$ & $11.27 * * *$ & $11.27 * * *$ & $11.27 * * *$ & $11.27 * * *$ & $11.27 * * *$ & $11.27 * * *$ \\
\hline & Production & $13.36^{* * * *}$ & $13.36^{* * *}$ & $13.36^{* * *}$ & $13.36^{* * *}$ & $13.36^{* * *}$ & $13.36^{* * *}$ & $13.36^{* * *}$ \\
\hline & Productivity & $2.09^{*}$ & $2.09^{*}$ & $2.09^{*}$ & $2.09^{*}$ & $2.09^{*}$ & $2.09^{*}$ & $2.09^{*}$ \\
\hline \multirow{3}{*}{ 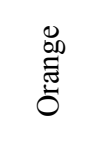 } & Area & $7.04 * * *$ & - & $14.37 * * *$ & $14.37 * * *$ & $14.37 * * *$ & $14.37 * * *$ & $14.37 * * *$ \\
\hline & Production & $15.78 * * *$ & - & $12.02 * * *$ & $12.02 * * *$ & $12.02 * * *$ & $12.02 * * *$ & $12.02 * * *$ \\
\hline & Productivity & $8.74 * *$ & - & -2.35 & $3.66 * *$ & 2.79 & $4.22 * *$ & $1.69 * * *$ \\
\hline
\end{tabular}

${ }^{* * * *},{ }^{* *},{ }^{*}$ indicates $1 \%, 5 \%$ and $10 \%$ level of significance.

Source: DAE

During the study period, the growth rate of production and productivity for mango in different upazilas were significantly increased. Highest production growth rate was found for Naniarchar upazila (16.1\%) followed by Dighinala upazila $(15.93 \%)$ and the lowest $(3.9 \%)$ for Sreemongal upazila (Table 1). Similarly, the highest growth rate in productivity was obtained for Naniarchar upazila (14.93\%) followed by Juri upazila $(7.29 \%)$ and the lowest for Sreemongal $(1.02 \%)$ per annum respectively. Dewan et al. (2015) reported that, in Khagrachari hill district, average annual growth rate of production was positive in almost all fruits except banana and pineapple. The highest growth rate of production was recorded in mango.

It was observed from table 1 that the growth rate of production and productivity for most of the study areas were increased significantly and the rate of increase was higher for some locations. In most of the locations mango cultivation is increasing but the production and productivity was significantly higher than area increased. The reason behind such results might be due to the adoption of new technologies by the new settlers (Bengalis) in the hill regions.

The growth rate of area for jackfruit in all the locations were significantly positive at different level per annum during the study period. Rangamati sadar and Matiranga 
upazila showed significantly positive but lower growth rate in area for jackfruit cultivation. The area of Dighinala, Naniarchar, Juri and Bandarban sadar upazila showed significantly higher growth rate ranging from $6.3 \%$ to $10.84 \%$ (Table 1 ). The growth rate of production for all locations were increased significantly except for Rangamati sadar upazila where it decreased by $0.28 \%$ per annum during the study period. The growth rate of productivity for jackfruit at Juri, Matiranga, Dighinala, Naniarchar and Bandarban sadar upazila were increased significantly at the rate of $10.27 \%, 2.54 \%, 7.15 \%, 7.01 \%$ and $2.57 \%$ per annum respectively at $1 \%$ and $5 \%$ level where as in Rangamati sadar it decreased with negative sign $(0.96 \%$ per annum) though it is not significant. It was observed that in Rangamati sadar upazila, area increased by $0.67 \%$ per annum but production and productivity were decreased. The reason might be due to use of poor quality seeds/local variety as well as poor management practices were followed by the farmers in the study area.

The growth rate of area for litchi in selected upazilas was increased significantly with a range of $4 \%$ to $8.4 \%$ per annum (Table 1). It was observed that the area of litchi at Juri, Matiranga and Bandarban sadar upazila was increased significantly at an increasing rate $(7.3 \%$ to $8.4 \%)$ and the area of litchi at Rangamati, Dighinala and Naniarchar upazila was increased at decreasing rate (4\% to $5.89 \%)$. The reason might be due to some other factors like comparative economic advantages of other competitive fruits cultivation in the study areas. The growth rate of production for litchi in the selected upazilas was increased significantly with positive sign for all locations during the period with a range of $5.01 \%$ to $14.84 \%$ per annum. The growth rate of productivity for different locations were also increased but it was only significant for Dighinala , Juri and Bandarban sadar upazila by $1.34 \%, 6.87 \%$ and $6.43 \%$ at $1 \%, 5 \%$ and $10 \%$ level respectively. The growth rate of productivity was increased in others upazilas like Matiranga, Naniarchar and Rangamati sadar but not significant.

It can be concluded that the area and production under litchi cultivation are still increasing. But productivity was not increased at satisfactory level. This indicates the lack of proper management practices as well as lack of improved variety in the study area for obtaining higher productivity.

Area of banana for different upazilas was significantly increased with highest growth rate at Dighinala (10.96\%) and lowest at Bandarban sadar upazila (1.28\%). Increase of banana cultivation was mainly caused due to utilization of fallow hilly land by adopting locally available technologies by the farmers (Table 1). Production and productivity are significantly increased in recent period. Growth rate of production $(19.77 \%)$ and productivity $(8.81 \%)$ was also higher in Dighinala upazila. Production growth rate were found higher than the productivity growth rate. Farmers used local variety of Bangla and Chapa following traditional management practices but obtained satisfactory productivity. However there exists the potentiality of increasing production and productivity by adopting HYV of banana along with appropriate production technologies against existing variety.

The areas for pineapple cultivation in different upazilas are increased significantly with a highest growth rate at Juri upazila (11.27\%) and the lowest for Rangamati sadar (1.64\%). It might be due to shifting of hilly land area to this fruit cultivation. Suitability for pineapple cultivation may be another reason for 
increasing land area under pineapple cultivation in the study areas. (Table 1). The growth rate of production for different upazilas were increased significantly by $(2.69 \%$ to $16.93 \%)$ per annum respectively with a highest production growth rate at Matiranga and the lowest at Rangamati sadar upazila. The productivity growth rate of pineapple in all selected upazilas were also increased significantly at lower rate in compare to area and production per anumm in the study period. The productivity growth rate was the highest at Matiranga (6.29\%) and the lowest at Bandarban sadar $(0.79 \%)$ per annum. The rate of increase was found at satisfactory level in case of area, production and productivity for the recent period which indicates that improved method of cultivation are gradually adopting by the farmers in all hilly areas under existing situation.

The growth rate of area for orange cultivation in all selected upazilas were increased significantly with a highest growth rate at Matiranga upazila (14.37\%) per annum while the lowest at Bandarban sadar upazila $(4.36 \%)$ per annum (Table 1). It is interested to note that, the availability of land area for orange cultivation in different upazila's are increasing at a higher rate due to initiation of orange development project in hilly areas taken by the govement and other different NGO's. Presently, the orange cultivation as a new crop has earned an economic advantage in hilly areas of Bangladesh. Though growth rate in production was increased but productivity was not increased compare to growth rate of area and production. It might be due to the lack of adoption of modern technologies, lack of cooperation with research and extension personnel, lack of proper plant protection measures along with other production practices followed by the farmers. In the recent years demand for hilly orange is increasing in different district markets and in the country as a whole.

In order to more increase of the productivity it is needed to increase the growth rate of production more. To increase the growth rates of production following strategies are proposed:

$>$ Availability of high yielding variety and improved cultivation method

$>$ Availability of irrigation and storage facilities

$>$ Establishment of better marketing infrastructures and facilities like farm to market roads and sale centers

$>$ Development of farmers skill about fruits cultivation through extension services

$>$ Better utilization of skilled labour and technical knowledge

\section{References}

Bairwa K. C., R. Sharma and T. Kumar. 2012. Economics of Growth and Instability: Fruits Crop of India, Raj. J. Edu. 20: 128-132.

Dewan B., F. Sarker, M. N. Alam. 2015. Marketing System in Chittagong Hill Tracts. International Journal of Economics, Commerce and Management. United kingdom Vol.III, Issue 5: 966-977.

Gujarati, D. N. 1998. Basic Econometrics, 4th ed., MC Graw-Hill, inc. P. 169.

Siddiqu. 2001. Litchi Production in Bangladesh.

Wasim, M. P. 2011. Trends, Growth and Variability of Major Fruit Crops in BalochistanPakistan: 1989-2009, ARPN Journal of Agricultural and Biological Science, 6(12): 27-36. 